\title{
Zooplankton as natural live food for three different fish species under concrete ponds with mono-and polyculture conditions.
}

\author{
Ahmed Abd El-Rahman Hassan \\ Department of Fish Production and Aquaculture Systems, Central Laboratory for Aquaculture Research \\ (CLAR), Agricultural Research Center., Egypt.
}

\begin{abstract}
The present study was conducted to evaluate the effect of using zooplankton as a live food for Nile tilapia (Oreochromis niloticus), mullet (Mugil cephalus) and common carp (Cyprinus carpio) under monoculture and polyculture condition in concrete ponds on water quality, plankton abundance, growth, survival, stomach content and chemical composition of experimental fish. Twenty four concrete ponds were used at the Central Laboratory for Aquaculture Research (CLAR), Abbassa-Sharkia Governorate- Egypt. The experimental period extended for 140 days. The results showed that, water $\mathrm{pH}$, nitrogen compounds $\left(\mathrm{NH}_{4}, \mathrm{NO}_{2}\right.$ and $\left.\mathrm{NO}_{3}\right)$, dissolved oxygen and chlorophyll "a" significantly increased in ponds of artificial feed than those of zooplankton live food only. Using of zooplankton as a live food for fish improved the quality of fish. The water quality did not significantly $(\mathrm{P}>0.05)$ differ between monoculture and polyculture in the same feeding regimes. The results indicated also that, using zooplankton as a live food for fish species significantly $(\mathrm{P}<0.05)$ increased growth performance than those fed artificial feed. On the other hand, the growth performance of common carp has significantly $(\mathrm{P}<0.05)$ increased than Nile tilapia and mullet. Also, zooplankton was enough for fish to achieve suitable growth more than artificial feed. The detritus increased significantly in case of fish species fed with artificial feed, while it did not increase significantly in zooplankton live food treatments.
\end{abstract}

Key words: live food, artificial food, tilapia, mullet, common carp, monoculture, polyculture, concrete ponds.

\section{INTRODUCTION}

Tilapia (Oreochromis niloticus), mullet (Mugil cephalus) and common carp (Cyprinus carpio) are popular fish often stocked in aquaculture fish farms in Egypt, (Shaker, 2008). Pond culture is the most commonly used production system among small-scale farmers in developing countries. Compounded diets are unavailable and the farmers often use manures (animal excreta or compost) or inorganic fertilizers with inexpensive feed materials. Diets in aquaculture are mostly based on conventional feedstuffs such as fish oils and fishmeal but these are expensive for small fish farms. Attention is now being focused to the wiser use of the available resources on the farm. One major resource is the waste from agriculture of both animal and vegetable origins, either directly from the farm or as by- 
product of processing plants (Schlechtriem et al., 2004).

Zooplanktons are an important food source for many fish larvae, post larvae and juvenile as well as crustaceans (Shaker et al., 2008). Mass culture of zooplankton has been attempted to utilize them as a live food in aquaculture (Payne and Rippingale, 2001).

Polyculture is the only possible way of simultaneously producing more than one fish species from the same rearing space (Papoutsoglou et al., 2001). The principle of polyculture is based on the fact that cultured fish species feed on different levels of food chain and environment (Milstein et al., 2002). The productivity of the aquatic system is thus increased by more efficiently utilizing ecological resources within the environment. Stocking two or more complimentary fish species can increase the maximum standing crop of a pond by allowing a wide range of available food items and the pond volume to be utilized.

When $O$. niloticus in semiintensive ponds are supplemented with low-protein feeds, dietary protein is largely provided by the natural food. Hepher (1988) and Schroeder et al. (1990) reported that natural food contributed between 300 and $500 \mathrm{~g} / \mathrm{kg}$ of growth when tilapia was supplemented with artificial feeds in fertilized ponds. The protein content of natural food ranges between 550 and $700 \mathrm{~g} / \mathrm{kg}$ on a dry matter basis (Hepher, 1988). This is above the range $(270-350 \mathrm{~g} / \mathrm{kg}$ ) recommended for intensive culture of Nile tilapia (El-Sayed, 1998).
First-feeding larvae, generally depend on live food. While live food is difficult to sustain and requires considerable space and expense, micro diets are easier to maintain and usually have lower production costs (Jones et al., 1993 and Person-Le Ruyet et al., 1993). The development of formulated diets allows for production of valuable fish larvae without using live prey. The possibility of replacing live feed with manufactured diets from the onset of exogenous feeding has been investigated in several studies (Jones et al., 1993 and Person-Le Ruyet et al., 1993). Limited success has been achieved in first-feeding larvae with the complete replacement of live feeds.

Wang et al. (2005) found that the survival was significantly higher in larvae fed live food than in larvae fed the three formulated diets. Introduction of live zooplankton is therefore being investigated as an alternate to pond fertilization for increasing fish yields while avoiding water quality deterioration (Jha et al., 2007). A variety of environmental factors are known to affect zooplankton production. Recent research has focused on the relative importance of food quantity and quality (Cole et al., 2002). The present study has been conducted to evaluate the effects of live food and formulated diets on the growth, survival, chemical composition and stomach index data of tilapia, mullet and common carp.

\section{MATERIALS AND METHODS}

This study was carried out at the Central Laboratory for Aquaculture Research, Abbassa, 
Abou-Hammad,

Sharkia

Governorate, Egypt. Nile tilapia (Oreochromis niloticus), and common carp (Cyprinus carpio) were obtained from aprivate hatchery at Abbassa, Abou-Hammad, Sharkia Governorate while the mullet (Mugil cephalus) was obtained from Bogaz El-Gamil- Port Saeed Governorate. The average weight was $1.0 \mathrm{~g}$ for all experimental fish species. Fishes were randomly distributed into four groups of concrete ponds $(2.5 \mathrm{~m}$ long $\mathbf{x} 1.5 \mathrm{~m}$ wide $\mathrm{x} 1.25 \mathrm{~m}$ depth). The first, second and third groups for monoculture of Nile tilapia, (Oreochromis niloticus), mullet (Mugil cephalus) and common carp (Cyprinus carpio) and the fourth group for Nile tilapia, mullet and common carp polyculture system. Each group was divided into two subgroups, the first subgroup was fed only zooplankton, the second subgroup was fed artificial feed only. The experimental period extended for 140 days from May to September 2009. Experimental fish were stocked at the rate of $12 \mathrm{fish} / \mathrm{m}^{2}$ or 63 fish/pond; in polyculture 38, 19 and 6 for tilapia, mullet and common carp respectively. Physico-chemical pond water parameters were monitored monthly. Temperature and dissolved oxygen were determined by a portable digital oxygen meter (YSI model 58, USA), $\mathrm{pH}$ was measured using a digital $\mathrm{pH}$ meter (Accumet 340). Ammonia, nitrite, nitrate and chlorophyll a were determined according to APHA, (2000). Chlorophyll a concentration was calculated using the following equation:

Chlorophyll a in $\mu \mathrm{g} / \mathrm{l}=11.9$ (A665A750) V/Lx1000/s
Where: A665 $=$ absorbance at $665 \mathrm{~A}$, A750 absorbance at $750, \mathrm{~V}=$ acetone extract in $\mathrm{ml}, \mathrm{L}=$ length path in the spectrophotometer in $\mathrm{cm}, \mathrm{S}=$ volume in $\mathrm{ml}$ of filtered sample.

Qualitative and quantitative estimates of phytoplankton and zooplankton were also recorded monthly according to APHA (2000). At the end of the experiment, fish were harvested, counted and weighed. The growth parameters were calculated as follows:

Daily gain $(\mathrm{DG})=\left(\mathrm{Wt}_{2}-\right.$ $\left.\mathrm{Wt}_{1}\right) / \mathrm{T}$; Specific growth rate (SGR) $=\left(\mathrm{Ln} \mathrm{Wt}_{2}-\mathrm{LnWt}_{1}\right) \times 100 / \mathrm{T}$; where $\mathrm{Wt}_{1}$ is the initial weight in grams, $\mathrm{Wt}_{2}$ is the second weight in grams, and $\mathrm{T}$ is the period in days.

Stomach contents analysis.

At the end of the experiment, a sample of thirty fish was taken from each treatment. The fish were dissected and stomachs removed and stored in $10 \%$ formalin solution. The stomachs were weighed, dissected and the constituent food items separated, enumerated under light microscope and weighed (Meschiatti and Arcifa, 2002). Plant fragments were differentiated from detritus on the basis of color, shape and cell structure. Differentiation of plankton and detritus was based on subjective indicators such as physical integrity. The stomach contents were grouped as detritus, higher plants, phytoplankton, zooplankton (Brummett, 2000), insects and 'others' categories could not be well identified. The numerical percentages of the total particles in the stomach content were calculated based on weight (Bubinas and Lozys, 2000). 


\section{Mass production of live food organisms.}

The freshwater zooplankton species was mass produced in lab until transfer to fiberglass tank of 1ton (t) filled with filtered tap water. Each tank was inoculated with 2 million organisms obtained from pure stock of zooplankton maintained in the laboratory. Batch cultures of zooplankton were fed Chlorella sp. (10-50 × $10^{6}$ cells $\left.\mathrm{ml} / 1\right)$ according to Shaker and Hamed, (2008) which was mass-produced using a commercial grade complete fertilizer (18-18-18) at $100 \mathrm{~g} /$ ton (tank). Every week, 2 tanks were transferred from lab to outdoor concrete ponds to be used as live food. Zooplanktons (150-250 $\mu \mathrm{m})$ were harvested with a plankton net after 1-2 weeks of culture.

Two feeding types were set: (artificial feed with $25 \%$ protein and live food of zooplankton in four treatments with three replicates each for each subgroup in a completely randomized design. Tilapia, mullet and common carp in monoculture and in polyculture were fed live organisms daily at a rate of 60,80 , 100, 120 and 140 1/pond during May, June, July, August and September respectively throughout the experiment. All diets were provided twice daily, 5 days/week.

\section{Statistical analysis.}

This was performed using the analysis of variance (ANOVA). Duncan's (1955) Multiple Range Test was used to determine the significant differences between means at $\mathrm{P}<0.05$. Standard errors of treatment means were also estimated. All statistics were carried out by using
Statistical Analysis Systems program (SAS, 2000).

\section{RESULTS AND DISCUSSION Water quality.}

Polyculture is commonly applied semi-intensively in ponds where the flow of nutrients through the food web depends largely on nutrient availability in the water column. Nutrients are predominantly supplied as fertilizer and/or feed; yet, in ponds that receive protein pellets, less than approximately $35 \%$ of the supplied nitrogen $(\mathrm{N})$ and phosphorous $(\mathrm{P})$ are retained in fish biomass (Rahman et al., 2008). The measurements of some physico-chemical parameters in water under different feeding types and aquaculture systems are shown in Table (1). Results revealed that differences among the applied treatments of water temperature were not significant and ranged between 27.5 and $28.5^{\circ} \mathrm{C}$. The $\mathrm{pH}$ values in pond water of the treatments ranged from 7.4 to 7.8 . The $\mathrm{pH}$ values did not significantly differ $(\mathrm{P}>0.05)$ among treatments during the experimental period. This variation could be explained by the photosynthetic uptake of $\mathrm{CO}_{2}$ and bicarbonate that substituted hydroxyl ions. Also, the polyculture system was not significantly differing in the same feeding types. These results indicate that the feeding types and the aquaculture systems did not significantly $(\mathrm{P}>0.05)$ affect $\mathrm{pH}$ values.. Similar observation was reported by Shaker (2008) and Shaker et al. (2008).

Dissolved oxygen (DO, mg/l) concentration ranged from 5.8 to 6.8 $\mathrm{mg} / \mathrm{l}$ in all fish ponds fed by zooplankton and ranged from 3.4 to 
$4.6 \mathrm{mg} / \mathrm{l}$ in fish ponds fed by artificial feed. DO concentrations in tilapia ponds, mullet ponds and common carp ponds did not vary significantly ( $P>0.05)$ under the same feed, while the difference was significant between tilapia, mullet and common carp ponds under different feeding types. The dissolved oxygen concentration in zooplankton ponds of tilapia; mullet and common carp was significantly $(\mathrm{P}<0.05) \quad$ higher than in tilapia; mullet and common carp fed by artificial feed. These results indicate that the DO was affected by feeding types not by fish species. Which may be due to the waste of artificial feed which is organic matter, where its decomposition requires $\mathrm{O}_{2}$, so DO decreased in these ponds. The temperature, $\mathrm{pH}$, dissolved oxygen and nitrogen compounds (ammonia, nitrite and nitrate) were the most influencing parameters in fish ponds. Although the values in all ponds fluctuated from time to time, they remained within the acceptable and favorable levels required for survival, growth and well being of the tested fish species.

The average level of ammonia nitrogen ( $\mathrm{N}$-ammonia) in ponds fed by zooplankton ranged from 0.6 to $0.8 \mathrm{mg} / \mathrm{l}$, while in treatments fed by artificial feed ranged from 1.4 to 1.8 $\mathrm{mg} / \mathrm{l}$. Shaker (2008) reported higher values of ammonia in fertilizer fish ponds. The increase of $\mathrm{NH}_{3}-\mathrm{N}$ in artificial fish feed ponds compared to zooplankton as live food for fish may be due to the decomposition of organic matter (feed waste) and via the direct excretion of ammonia by the large biomass of fish. Merino et al. (2007) found that total ammonia nitrogen (TAN) excretion rates are directly related to dietary nitrogen and protein intake in fish .TAN indicates the main nitrogenous excretion product from fish while typically constitutes 80 to $90 \%$ of the total nitrogen excreted. The relationship between feed offered and TAN excretion has been reported for some flatfish species to be between 12 and $25 \mathrm{~g} / \mathrm{kg}$ feed. The TAN concentrations measured were below the toxicity levels reported in the literature for other flatfish species. Therefore, the fish were not exposed to dangerous levels of TAN.

The total ammonium nitrogen (TAN) concentration is often a key limiting water quality parameter in intensive and semi intensive aquaculture systems. Fish stocking densities in aquaculture systems are limited primarily by the dissolved oxygen (DO) concentrations and, also by the ammonia $\left(\mathrm{NH}_{3}\right)$ concentrations. Ammonia is formed as the principal end product from protein metabolism in fish.

The $\mathrm{NO}_{2}$ and $\mathrm{NO}_{3}$ concentrations in water followed the same trend of ammonia-nitrogen. The concentrations of $\mathrm{NO}_{2}$ and $\mathrm{NO}_{3}$ were also higher in artificial feed treatments. These results may be due to the consumption of $\mathrm{N}$-ammonia (which is an essential nutrient) by phytoplankton communities. It is of particular interest to notice a negative correlation between nitrate content and total phytoplankton which may be attributed to high consumption rate of $\mathrm{NO}_{3}-\mathrm{N}$ by the dense vegetation. These results are in harmony with those obtained by Shaker et al. (2002) and Moussa (2004). The average values of 
chlorophyll a of tilapia; mullet and common carp fed zooplankton were $14.58 ; 12.98 ; 12.24$ and $15.08 \mu \mathrm{g} / \mathrm{l}$ monoculture and polyculture, respectively. The average values of chlorophyll a in the above treatments fed by artificial feed were 36.72 ; $30.44 ; \quad 54.22$ and $51.25 \mu \mathrm{g} / \mathrm{l}$, respectively (Table 1). Significantly higher amounts of chlorophyll a were recorded in all ponds fed by artificial feed, indicating a higher level of phytoplankton production. Also, there were no significant difference between monoculture and polyculture. This is consistent with the work reported by Shaker and Abdel-Aal (2006) with higher inputs of artificial feed in semi-intensive earthen ponds at Manzala fish farm. Total and classification of phytoplankton and zooplankton are illustrated in Tables ( $\& 3)$. The identification of phytoplankton and zooplankton were classified to four groups. The main group of phytoplankton was blue green then green. The total numbers of phytoplankton were 308; 328; 338 and 348 org/l for tilapia, mullet and common carp in monoculture treatments and polyculture treatment, respectively fed by zooplankton. In the same treatments fed by artificial feed were they 630; 566; 706 and $743 \mathrm{org} / \mathrm{l}$ for tilapia, mullet and common carp in monoculture treatments and polyculture treatment, respectively. The total numbers of phytoplankton were significantly higher in artificial feed than in zooplankton feed. These results may be due to the waste of feed in these treatments which led to increase the nutrients that increased phytoplankton. The same trend was observed by zooplankton numbers. The total numbers of zooplankton were $37 ; 39 ; 43$ and 44 org/l for tilapia, mullet and common carp in monoculture treatments and polyculture treatment respectively fed by zooplankton. In the same treatments fed by artificial feed they were 88; 100113 and 114org/l, respectively. These results are in agreement with those obtained by Shaker et al. (2008) who reported that the phytoplankton and zooplankton populations depend on pond management, specially fertilizers and feeds. Significantly higher amounts of chlorophyll a in Table (1) were recorded in all ponds fed by artificial feed, indicating higher level of phytoplankton production. This is consistent with the work reported by Shaker and Abdel-Aal (2006) with higher inputs of artificial feed in semi-intensive earthen ponds at Manzala fish farm.

\section{Growth performance.}

Fish production and growth performance parameters are illustrated in Table (4). The average final weights of Nile tilapia fed by zooplankton and artificial feed in monoculture were 145 and $110 \mathrm{~g}$, respectively. The average final weights of mullet fed by zooplankton and artificial feed in monoculture were 115 and $100 \mathrm{~g}$, respectively. The average final weights of common carp fed by zooplankton and by artificial feed in monoculture were 185 and 160, g respectively. The average final weights of tilapia, mullet and common carp fed by zooplankton in polyculture were 145 , 115 and $175 \mathrm{~g}$, respectively. The average final weights of tilapia, mullet and common carp fed by 
artificial feed in polyculture were 110, 110 and $155 \mathrm{~g}$, respectively. Significant differences among the treatments continued to the end of the experiment. Generally, the final weight, net gain and daily gain increased significantly in all fish species except mullet feeding by zooplankton. Shaker (2008) and Shaker et al. (2008) reported that the final weight depends on initial weight and pond management, while the live food is more suitable for different fish species. The growth performance of common carp showed significantly $(\mathrm{P}<0.05)$ higher final weight, daily gain, net gain and total unlike.

Nile tilapia and mullet as shown in Table (4). These results may be due to that zooplankton diets are more digested than artificial feed. Mullet showed significantly $(\mathrm{P}<0.05)$ lower survival rate in monoculture and polyculture fed by zooplankton and artificial feed than other fish species. Wilcox et al. (2006) found that the production of marine fish species increased with increasing natural feeds such as rotifers (Brachionus sp.) or brine shrimps (Artemia sp.). Also, they reported that a feed density of $\geq 4000$ rotifers/ 1 gives better survival and growth than lower densities. In the present study, the feed density ranged from 4000 to 5000 organism/l.

\section{Fish body composition.}

Moisture, ash, fat, and protein contents showed significant $(\mathrm{P}<0.05)$ differences among fish species (Table $5)$. The highest values of moisture content were recorded in common carp and tilapia, while the lowest values in mullet. These results agree with those obtained by Shaker and
Mahmoud (2007) in case of silver carp reared in cages in River Nile.

From the data presented in table (5), it is obvious that the chemical composition showed that tilapia and mullet fed by zooplankton had significantly $(\mathrm{P}<0.05)$ higher contents of protein than other fish species fed by artificial feed. These results may be due to the high protein content in zooplankton than artificial feed diets.

The same trend was observed in case of fat content. These results indicate that the use of zooplankton as a live food for different fish species increased protein and fat contents, and in the mean time decreased ash content. These findings suggested the use of zooplankton as a live food for fish to improve the quality of fish. The use of zooplankton as a live food for fish species led to a sharp decrease of ash percentage (about 40-50\%) and increased the protein and fat contents.

\section{Stomach contents}

The stomach contents of fish varied significantly $(\mathrm{P}<0.05)$, depending on the type of feed used. From the data presented in Table (6), it is clear that all fish species fed by artificial feed had significantly $(\mathrm{P}<0.05)$ higher detritus $(44.2-47.7$ $\%)$ than zooplankton (7.8-14.2\%). The same trend was observed by phytoplankton and insects.

The highest values of phytoplankton and insects were recorded in tilapia, mullet and common carp fed by artificial feed. While, the lowest values were recorded in the same species fed by zooplankton. These results indicate that zooplankton is enough for fish metabolism while consequently 
results in suitable growth than artificial feed. Insects were not reported in large amounts but detritus was highly frequent across treatments. The stomach contents of fish in this experiment varied from detritus, higher plants, zooplankton, phytoplankton to insects. Shaker (2008) found the same categories of stomach contents in tilapia, carp and catfish in earthen ponds under different fertilization types. It is obvious that fish cultured in artificial feed treatments consumed significantly higher amounts of detritus followed by phytoplankton and insects. Fish above $100 \mathrm{~g}$ consumed high amounts of detritus similar to that reported by Brummett (2000) and Shaker (2008). Fish in the artificial feed ponds preferred higher plants, phytoplankton and detritus and reduced their intake of zooplankton. Shaker (2008) found that insects were rarely found in stomachs of the fish. Also, fish in zooplankton feed preferred zooplankton, small amount of insects, phytoplankton and detritus. Tilapia is believed to change feeding habits from carnivorous when young (7$33 \mathrm{~mm}$ ) and consume zooplankton, aquatic insects and detritus, which make up about $26 \%$ of their stomach contents in the wild (Meschiatti and Arcifa, 2002). They return herbivorous as they grow (Brummett, 2000). Detritus was one of the important stomach contents encountered during the analysis in artificial feed treatments, while zooplankton was one of the important stomach contents encountered during the analysis.

\section{CONCLUSION}

In conclusion, it can be stated that zooplankton was enough for feeding of tilapia, mullet and common carp to achieve a suitable growth and better quality of fish.

\section{REFERENCES}

$\begin{array}{llr}\begin{array}{c}\text { American } \\ \text { Association }\end{array} & \begin{array}{l}\text { Public } \\ \text { (APHA) }\end{array} & \begin{array}{r}\text { Health } \\ (\mathbf{2 0 0 0 )}\end{array} \\ \begin{array}{l}\text { Standard } \\ \text { Examination }\end{array} & \text { Methods Water and } & \text { for } \\ \text { WasteWater, 21th edn. American } \\ \text { Public Health Association, } \\ \text { Washington, DC, USA, 1268pp. } \\ \text { Association of } \\ \text { Chemists (AOACial Analytical } \\ \text { Methods of Analysis, 15th edn. } \\ \text { AOAC, Washington, DC, USA. }\end{array}$

Brummett, R. E. (2000): Food organism availability and resource partitioning in organically or inorganically fertilized Tilapia rendalli ponds. Aquaclt., 183, 5771.

Bubinas, A. and L. Lozys. (2000): The nutrition of fish in the Curonian lagoon and the coastal zone of the Baltic Sea. Acta Zoolog., 10, 5-12.

Cole, P. C., C. Luecke, A. Wayne, A. Wurtsbaugh and G. Burkart. (2002): Growth and survival of Daphnia in epilimnetic and metalimnetic water from oligotrophic lakes: the effects of food and temperature. Freshwater Biolo., 47, 2113-2122.

Duncan, D. B. (1955): Multiple range and multiple F-tests. Biometrics11, 1-40. 
El-Sayed, A. F. M. (1998): Total replacement of fish meal with animal protein sources in Nile tilapia Oreochromis niloticus (L) feeds. Aquac. Res., 29, 275-280.

Hepher, B. (1988): Principles of fish nutrition. In: Fish Culture in Warm water systems, Problems \& Trends (Shilo, M. \& Sarig, S. eds), pp. 121-142. CRC Press, New York, USA.

Jha, P., S. Barat and K. Sarkar. (2007): Comparative effect of live food and manured treatments on water quality and production of ornamental carp, Cyprinus carpio var. koi L., during winter, summer, monsoon and postmonsoon grow out experiments in concrete tanks. J. Appl. Ichthyol., 23, 87-92

Jones, D. A., M. H. Karnarudin and L. Le Vay. (1993): The potential for replacement of live feeds in larval culture. J. World Aqua. Soc., 24, 199-207.

Lutz C.G. (2003): Polyculture: principles, practices, problems and promise. Aquac. Magaz., 29, 34-39.

Merino E. G.; H. R Piedrahita,. And E. D. Conklin (2007): Ammonia and urea excretion rates of California halibut (Paralichthys californicus, Ayres) under farm-like conditions. Aquac., 271, 227-243.

Meschiatti, A. J. and M. S. Arcifa. (2002): Early life stages of fish and the relationships with zooplankton in a tropical Brazilian reservoir: Lake Monte
Allegro. Braz. J. of Biolo., 62; 4150 .

Milstein A., M.A. Wahab and M.M. Rahman (2002): Environmental effcts of common carp Cyprinus carpio (L.) and mrigal Cirrhinus mrigala (Hamilton) as bottom feeders in major Indian carp polycultures. Aquac. Res., 33, 1103-1117.

Moussa, S. M. S. (2004): Impact of inorganic pollutants on aquatic environment and fish performance in Lake Borollus. Ph. D. Thesis, Inst. of Environment Stud. and Res., Biol. \& Phys. Dep., Ain hams Univ., Egypt.

Papoutsoglou S.E., H. Miliou, N.P.Karakatsouli, M.Tzitzinakis and S.Chadi., (2001): Growth and physiological changes in scaled carp and blue tilapia under behavioural stress in mono- and polyculture rearing using a recirculated water system. Aquac. Inter., 9, 509-518.

Payne, M.F.,and R. J. Rippingale, (2001): Intensive cultivation of the calanoid copepod Gladioferens imparipes. Aquac., 201, 329-342.

Person-Le Ruyet, J., J. C. Alexandre, L. Thebaud and $\mathrm{C}$. Mugnier (1993): Marine fish larvae feeding: formulated diets or live prey. J. World Aquac. Soc., 24, 211-224.

Rahman M.M.; M. M.; Q. Jo; Y.G. Gong; S.A. Miller and M.Y. Hossain (2008): A comparative study of common carp (Cyprinus carpio L.) and calbasu (Labeo calbasu Hamilton) on bottom soil 
resuspension, water quality, nutrient accumulations, food intake and growth of fish in simulated rohu (Labeo rohita Hamilton) ponds. Aquac., 285, 78-83.

\section{Schlechtriem, C, U. Focken and K.} Becker. (2004): Stable isotopes as a tool for nutrient assimilation studies in larval fish feeding on live food. Aquatic Ecolo., 38, 93 100 .

Schroeder, G. L., G. W. Wohlfarth, A. Alkon, A. Halevy and $H$. Krueger. (1990): The dominance of algal-based food webs in fish ponds receiving chemical fertilizers plus organic manures. Aquac., 86, 219-229.

Shaker, I. M. A. (2008): Effect of using different types of organic manure (compost, chicken, mycelium) and mineral fertilizer on water quality, plankton abundance and on growth performance of Oreochromis niloticus in earthen ponds. Abbassa, Int. J. qua. (1A), 203227.

Shaker, I. M. A. and A. A. Mahmoud. (2007): The biological load of silver carp cages in the River Nile and their effects on water quality and growth performance. Egypt. J. Aquat. Biol. \& Fish., 11 (2), 119143.

Shaker, I. M. A. and M. A. Hamed. (2008): The effect of green algae and yeast diets on population growth for rotifers and cladocerans. Impress. SPSS (1999) SPSS. SPSS, Chicago, IL, USA.
Shaker, I. M. and M. M. AbdelAal. (2006): Growth performance of fish reared under different densities in semi-intensive and extensive earthen ponds. Egypt. J. Aquat. Biol. \& Fish., 10 (4), 109127. ISSN 1110-6131.

Shaker, I.M.A.; A.H. Mona and M.M. Abd El Aal, (2008): Zooplankton as live food for fry and fingerlings of Oreochromis niloticus in concrete ponds. $8^{\text {th }}$ International Symposium on Tilapia in Aquac., 2, 757-771.

Shaker, I. M. A., N. A. Ibrahim, M. A. A. Dawa and A. H. Zakar. (2002): Effect of stocking density on water quality and mullet growth in earthen ponds at Sahl El-Teena-Senai- Egypt. The $6^{\text {th }} \quad$ Vet. Med. Zagazig. Conference, 7-9 Sep. 2002, Hurghada, Egypt.

Wang, C. S., K. Xie, X. Zheng, W. Zhu, Y. Lei, S. Yang and J. Liu. (2005): Effects of live food and formulated diets on survival, growth and protein content of first-feeding larvae of Plelteobagrus fulvidraco. J. Appl. Ichthyol., 21, 210-214

Wilcox, J. A.; P. Tracy and H. N. Marcus. (2006): Improving Live Feeds: Effect of a Mixed Diet of Copepod Nauplii (Acartia tonsa) and Rotifers on the Survival and Growth of First-Feeding Larvae of the Southern Flounder, Paralichthys lethostigma. Journal of the World Aquac. Soc., Vol. 37, No. 1. 
Table (1): Average means of water quality parameters in concrete ponds under different food types of tilapia, mullet and common carp during experiment period.

\begin{tabular}{|c|c|c|c|c|c|c|c|c|}
\hline Feed types & Fish species & $\begin{array}{l}\text { Temp. } \\
{ }^{\circ} \mathrm{C}\end{array}$ & pH & $\begin{array}{l}\mathrm{DO} \\
\mathrm{mg} / \mathrm{l}\end{array}$ & $\begin{array}{l}\mathrm{NH}_{3} \\
\mathrm{mg} / \mathrm{l}\end{array}$ & $\begin{array}{l}\mathrm{NO}_{2} \\
\mathrm{mg} / \mathrm{l}\end{array}$ & $\begin{array}{l}\mathrm{NO}_{3} \\
\mathrm{mg} / \mathrm{l}\end{array}$ & $\begin{array}{c}\text { Chlorophyll"'a' } \\
\mu \mathrm{g} / \mathrm{l}\end{array}$ \\
\hline \multirow{4}{*}{ Zooplankton } & Tilapia & $27.0 \pm 5 a$ & $7.8 \pm 0 . \mathrm{a}$ & $6.5 \pm 1 \mathrm{a}$ & $0.7 \pm 0 . c$ & $0.01 \pm 0 c$ & $0.07 \pm 0.0 \mathrm{c}$ & $14.58 \pm 1.2 \mathrm{c}$ \\
\hline & Mullet & $28.5 \pm 1 \mathrm{a}$ & $7.8 \pm 0 . \mathrm{a}$ & $6.8 \pm 1 \mathrm{a}$ & $0.60 .2 \mathrm{c}$ & $0.01 \pm 0 c$ & $0.06 \pm 0.0 \mathrm{c}$ & $12.98 \pm 1.4 \mathrm{c}$ \\
\hline & Common carp & $27.5 \pm 1 \mathrm{a}$ & $7.4 \pm 0 . \mathrm{a}$ & $5.8 \pm 1 b$ & $0.8 \pm 0 . c$ & $0.02 \pm 0 c$ & $0.1 \pm 0.02 b$ & $12.24 \pm 1.6 c$ \\
\hline & Poly & $27.5 \pm 1 \mathrm{a}$ & $7.8 \pm 0 . \mathrm{a}$ & $6.1 \pm 1 \mathrm{a}$ & $0.8 \pm 0 . c$ & $0.02 \pm 0 \mathrm{c}$ & $0.07 \pm 0.0 \mathrm{c}$ & $15.08 \pm 1.2 \mathrm{c}$ \\
\hline \multirow{4}{*}{ Artificial } & Tilapia & $27.0 \pm 1 \mathrm{a}$ & $7.6 \pm 0 . a$ & $4.4 \pm 1 c$ & $1.5 \pm 0 . \mathrm{a}$ & $0.05 \pm 0 b$ & $0.13 \pm 0.0 \mathrm{a}$ & $36.72 \pm 2.4 b$ \\
\hline & Mullet & $28.5 \pm 1 \mathrm{a}$ & $7.5 \pm 0 . \mathrm{a}$ & $4.6 \pm 1 c$ & $1.4 \pm 0 . b$ & $0.04 \pm 0 b$ & $0.12 \pm 0.0 \mathrm{a}$ & $30.44 \pm 2.2 b$ \\
\hline & Common carp & $28.5 \pm 1 \mathrm{a}$ & $7.8 \pm 0 . \mathrm{a}$ & $3.5 \pm 1 c$ & $1.8 \pm 0 . \mathrm{a}$ & $0.08 \pm 0 \mathrm{a}$ & $0.17 \pm 0.0 \mathrm{a}$ & $54.22 \pm 3.3 \mathrm{a}$ \\
\hline & Poly & $27.0 \pm 5 a$ & $7.8 \pm 0 . \mathrm{a}$ & $3.4 \pm 1 \mathrm{c}$ & $1.7 \pm 0 . \mathrm{a}$ & $0.07 \pm 0 \mathrm{a}$ & $0.15 \pm 0.0 \mathrm{a}$ & $51.25 \pm 2.4 \mathrm{a}$ \\
\hline
\end{tabular}

Table (2): Average of counting (organism /1) and identification in of phytoplankton the experimental ponds water.

\begin{tabular}{ccccccc}
\hline Feed types & Fish species & Blue-Green & Green & Bacillar & Cyanoph. & Total \\
\hline \multirow{4}{*}{ Zooplankton } & Tilapia & $122 \pm 10 \mathrm{~b}$ & $102 \pm 6 \mathrm{c}$ & $48 \pm 3 \mathrm{c}$ & $36 \pm 2 \mathrm{~b}$ & $308 \pm 165 \mathrm{~d}$ \\
& Mullet & $136 \pm 8 \mathrm{~b}$ & $112 \pm 6 \mathrm{c}$ & $46 \pm 3 \mathrm{c}$ & $34 \pm 2 \mathrm{~b}$ & $328 \pm 19 \mathrm{~d}$ \\
& Common carp & $142 \pm 7 \mathrm{~b}$ & $122 \pm 7 \mathrm{c}$ & $44 \pm 3 \mathrm{c}$ & $30 \pm 2 \mathrm{~b}$ & $338 \pm 18 \mathrm{~d}$ \\
& Poly & $146 \pm 10 \mathrm{~b}$ & $116 \pm 6 \mathrm{c}$ & $54 \pm 3 \mathrm{c}$ & $32 \pm 2 \mathrm{~b}$ & $348 \pm 165 \mathrm{~d}$ \\
& Tilapia & $276 \pm 15 \mathrm{a}$ & $222 \pm 14 \mathrm{~b}$ & $88 \pm 5 \mathrm{~b}$ & $44 \pm 3 \mathrm{a}$ & $630 \pm 44 \mathrm{~b}$ \\
Artificial & Mullet & $242 \pm 16 \mathrm{a}$ & $202 \pm 16 \mathrm{~b}$ & $82 \pm 8 \mathrm{~b}$ & $40 \pm 2 \mathrm{a}$ & $566 \pm 58 \mathrm{c}$ \\
& Common & $256 \pm 14 \mathrm{a}$ & $304 \pm 11 \mathrm{a}$ & $104 \pm 6 \mathrm{a}$ & $42 \pm 2 \mathrm{a}$ & $706 \pm 32 \mathrm{a}$ \\
& carp & $266 \pm 15 \mathrm{a}$ & $322 \pm 14 \mathrm{a}$ & $108 \pm 5 \mathrm{a}$ & $47 \pm 3 \mathrm{a}$ & $743 \pm 44 \mathrm{a}$ \\
\hline
\end{tabular}

Means in the column followed by different letters are significantly different $(\mathrm{P}<0.05)$ 
Table (3): Average of counting (organism /l) and identification of zooplankton in the experimental ponds water.

\begin{tabular}{lcccccc}
\hline Feed types & Fish species & Copepoda & Cladocera & Rotifera & Ostracoda & Total \\
\hline \multirow{4}{*}{ Zooplankton } & Tilapia & $8 \pm 1 \mathrm{c}$ & $7 \pm 0.5 \mathrm{~b}$ & $19 \pm 7.5 \mathrm{c}$ & $3 \pm 1.3 \mathrm{~b}$ & $37 \pm 0.5 \mathrm{c}$ \\
& Mullet & $8 \pm 1 \mathrm{c}$ & $8 \pm 0.4 \mathrm{~b}$ & $20 \pm 6.8 \mathrm{c}$ & $3 \pm 1.5 \mathrm{~b}$ & $39 \pm 1.1 \mathrm{c}$ \\
& Common carp & $11 \pm 4.5 \mathrm{~b}$ & $8 \pm 0.5 \mathrm{~b}$ & $20 \pm 2.3 \mathrm{c}$ & $4 \pm 4.3 \mathrm{~b}$ & $43 \pm 1.8 \mathrm{c}$ \\
& Poly & $12 \pm 1 \mathrm{~b}$ & $8 \pm 0.5 \mathrm{~b}$ & $21 \pm 7.5 \mathrm{c}$ & $3 \pm 1.3 \mathrm{~b}$ & $44 \pm 0.5 \mathrm{c}$ \\
Artificial & Tilapia & $18 \pm 5 \mathrm{~b}$ & $18 \pm 0.4 \mathrm{a}$ & $44 \pm 2.2 \mathrm{~b}$ & $8 \pm 4.4 \mathrm{a}$ & $88 \pm 1.2 \mathrm{~b}$ \\
& Mullet & $18 \pm 2 \mathrm{~b}$ & $17 \pm 0.3 \mathrm{a}$ & $56 \pm 8.4 \mathrm{a}$ & $9 \pm 1.1 \mathrm{a}$ & $100 \pm 0.5 \mathrm{a}$ \\
& common & $25 \pm 2 \mathrm{a}$ & $21 \pm 0.3 \mathrm{a}$ & $58 \pm 8.2 \mathrm{a}$ & $9 \pm 1 \mathrm{a}$ & $113 \pm 0.5 \mathrm{a}$ \\
& Poly & $26 \pm 5 \mathrm{a}$ & $22 \pm 0.4 \mathrm{a}$ & $58 \pm 2.2 \mathrm{a}$ & $8 \pm 4.4 \mathrm{a}$ & $114 \pm 1.2 \mathrm{a}$ \\
\hline \multicolumn{5}{c}{} & \multicolumn{7}{c}{ Means in the column followed by different letters are significantly different $(\mathrm{P}<0.05)}$. &
\end{tabular}

Table (4): Growth performance of Nile tilapia, mullet and common carp fed by zooplankton as a live food and artificial food in concrete ponds.

\begin{tabular}{|c|c|c|c|c|c|c|c|c|c|}
\hline Feed types & Fish species & System & $\begin{array}{c}\text { Fish } \\
\text { number }\end{array}$ & $\begin{array}{c}\text { Survival } \\
\%\end{array}$ & $\begin{array}{c}\text { Final } \\
\text { weight } g\end{array}$ & $\begin{array}{l}\text { Net gain } \\
\text { g }\end{array}$ & $\begin{array}{c}\text { Daily gain } \\
\text { g }\end{array}$ & $\begin{array}{c}\text { Total prod. } \\
\mathrm{g} / \mathrm{m}^{3}\end{array}$ & SGR \%/d \\
\hline \multirow{6}{*}{ Zooplankton } & Tilapia & Mono & 63 & $98.3 \pm 1.5 \mathrm{a}$ & $145 \pm 10.5 b$ & $144 \pm 10 b$ & $1.03 \pm 0.1 \mathrm{~b}$ & $1380 \pm 50 \mathrm{c}$ & $3.4 \pm 1 \mathrm{a}$ \\
\hline & Mullet & Mono & 63 & $75 \pm 3 c$ & $115 \pm 15 c$ & $114 \pm 8 c$ & $0.81 \pm 0.1 \mathrm{c}$ & $832.4 \pm 65 d$ & $1.55 \pm 0 . \mathrm{c}$ \\
\hline & Common carp & Mono & 63 & $100 \pm 0 \mathrm{a}$ & $185 \pm 8 \mathrm{a}$ & $184 \pm 8 \mathrm{a}$ & $1.3 \pm 0.1 \mathrm{a}$ & $2220 \pm 35 a$ & $3.25 \pm 0 . \mathrm{a}$ \\
\hline & Tilapia & Poly & 38 & $98.3 \pm 1.5 \mathrm{a}$ & $145 \pm 10.5 b$ & $144 \pm 10 b$ & $1.03 \pm 0.1 \mathrm{~b}$ & $1022 \pm 50 \mathrm{c}$ & $3.4 \pm 1 \mathrm{a}$ \\
\hline & Mullet & Poly & 19 & $75 \pm 3 c$ & $115 \pm 15 c$ & $114 \pm 8 c$ & $0.81 \pm 0.1 \mathrm{c}$ & $306.7 \pm 65 \mathrm{e}$ & $1.55 \pm 0 . \mathrm{c}$ \\
\hline & Common carp & Poly & 6 & $100 \pm 0 \mathrm{a}$ & $175 \pm 8 a$ & $174 \pm 8 \mathrm{a}$ & $1.24 \pm 0.1 \mathrm{a}$ & $200 \pm 35 e$ & $3.25 \pm 0 . \mathrm{a}$ \\
\hline \multirow{6}{*}{ Artificial } & Tilapia & Mono & 63 & $95 \pm 3 b$ & $110 \pm 10 \mathrm{c}$ & $109 \pm 1 \mathrm{c}$ & $0.78 \pm 0.1 \mathrm{c}$ & $1257 \pm 2 c$ & $1.22 \pm 0 . c$ \\
\hline & Mullet & Mono & 63 & $80 \pm 1.2 \mathrm{c}$ & $100 \pm 10 c$ & $119 \pm 3 c$ & $0.85 \pm 0.1 \mathrm{c}$ & $952.4 \pm 42 \mathrm{c}$ & $2.2 \pm 0.2 b$ \\
\hline & Common carp & Mono & 63 & $98 \pm 1.2 \mathrm{a}$ & $160 \pm 10 b$ & $159 \pm 14 b$ & $1.14 \pm 0.2 b$ & $1890 \pm 75 b$ & $2.62 \pm 0 . b$ \\
\hline & Tilapia & Poly & 38 & $95 \pm 3 b$ & $110 \pm 10 c$ & $109 \pm 10 \mathrm{c}$ & $0.78 \pm 0.1 \mathrm{c}$ & $754.3 \pm 2 d$ & $1.22 \pm 0 . c$ \\
\hline & Mullet & Poly & 19 & $75 \pm 1.2 \mathrm{c}$ & $110 \pm 10 \mathrm{c}$ & $119 \pm 3 c$ & $0.85 \pm 0.1 \mathrm{c}$ & $293 \pm 42 \mathrm{e}$ & $2.2 \pm 0.2 b$ \\
\hline & Common carp & Poly & 6 & $100 \pm 1.2 \mathrm{a}$ & $155 \pm 10 b$ & $154 \pm 14 b$ & $1.1 \pm 0.2 b$ & $177 \pm 75 \mathrm{e}$ & $2.62 \pm 0 . b$ \\
\hline
\end{tabular}


Table (5): Chemical composition (\% dry weight basis) of the whole fish body of tilapia, mullet and common carp under different feed types (zooplankton as live food and artificial food) in concrete ponds.

\begin{tabular}{ccccccc}
\hline Feed types & Fish species & System & Moisture & Protein & Fat & Ash \\
\hline & Tilapia & Mono & $77.5 \pm 2.5 \mathrm{~b}$ & $79.75 \pm 4.2 \mathrm{a}$ & $13.55 \pm 1.2 \mathrm{a}$ & $6.7 \pm 0.4 \mathrm{c}$ \\
& Mullet & Mono & $77.3 \pm 3.5 \mathrm{~b}$ & $79.25 \pm 2.4 \mathrm{a}$ & $13.75 \pm 1.1 \mathrm{a}$ & $7 \pm 0.4 \mathrm{bc}$ \\
Zooplankton & Common carp & Mono & $79.78 \pm 3.4 \mathrm{a}$ & $77.86 \pm 2.5 \mathrm{~b}$ & $13.92 \pm 1.1 \mathrm{a}$ & $8.22 \pm 0.6 \mathrm{~b}$ \\
& Tilapia & Poly & $78.28 \pm 3.4 \mathrm{a}$ & $77.44 \pm 2.8 \mathrm{~b}$ & $14.24 \pm 1.1 \mathrm{a}$ & $8.32 \pm 0.5 \mathrm{~b}$ \\
& Mullet & Poly & $78.18 \pm 3.4 \mathrm{a}$ & $77.86 \pm 2.5 \mathrm{~b}$ & $13.92 \pm 1.1 \mathrm{a}$ & $8.22 \pm 0.6 \mathrm{~b}$ \\
& Common carp & Poly & $79.88 \pm 3.4 \mathrm{a}$ & $77.44 \pm 2.8 \mathrm{~b}$ & $14.24 \pm 1.1 \mathrm{a}$ & $8.32 \pm 0.5 \mathrm{~b}$ \\
& Tilapia & Mono & $78.75 \pm 3.2 \mathrm{a}$ & $76.12 \pm 3.2 \mathrm{c}$ & $11.88 \pm 1.1 \mathrm{~b}$ & $12 \pm 0.4 \mathrm{a}$ \\
& Mullet & Mono & $77.68 \pm 3.2 \mathrm{~b}$ & $76.7 \pm 3.1 \mathrm{c}$ & $11.4 \pm 1.3 \mathrm{~b}$ & $11.9 \pm 0.6 \mathrm{a}$ \\
& Common carp & Mono & $79.86 \pm 2.4 \mathrm{a}$ & $76.2 \pm 2.4 \mathrm{c}$ & $11.5 \pm 1.4 \mathrm{~b}$ & $12.3 \pm 0.5 \mathrm{a}$ \\
& Tilapia & Poly & $77.8 \pm 2.8 \mathrm{~b}$ & $76.42 \pm 2.6 \mathrm{c}$ & $11.7 \pm 1.3 \mathrm{~b}$ & $11.88 \pm 0.6 \mathrm{a}$ \\
& Mullet & Poly & $77.6 \pm 2.4 \mathrm{~b}$ & $76.2 \pm 2.4 \mathrm{c}$ & $11.5 \pm 1.4 \mathrm{~b}$ & $12.3 \pm 0.5 \mathrm{a}$ \\
& Common carp & Poly & $79.8 \pm 2.8 \mathrm{a}$ & $76.42 \pm 2.6 \mathrm{c}$ & $11.7 \pm 1.3 \mathrm{~b}$ & $11.88 \pm 0.6 \mathrm{a}$ \\
\hline
\end{tabular}

Means in the column followed by different letters are significantly different $(\mathrm{P}<0.05)$. 
Table (6): Effect of different food types on stomach index \% of mullet and common carp.

\begin{tabular}{|c|c|c|c|c|c|c|c|c|}
\hline Feed types & Fish species & System & Detritus & $\begin{array}{l}\text { Higher } \\
\text { plants }\end{array}$ & Zooplankton & Phytoplankton & Insects & Others \\
\hline \multirow{6}{*}{ Zooplankton } & Tilapia & Mono & $9.5 \pm 1 b$ & $3.55 \pm 0.3 b$ & $73.85 \pm 7 . a$ & $105 \pm 1.3 \mathrm{~b}$ & $7.5 \pm 0.5 b$ & $2.6 \pm 0.2 \mathrm{a}$ \\
\hline & Mullet & Mono & $7.8 \pm 1 b$ & $3.6 \pm 0.4 b$ & $72.2 \pm 6.8 \mathrm{a}$ & $7.6 \pm 0.5 b$ & $6.6 \pm 0.3 c$ & $2.2 \pm 0.2 b$ \\
\hline & Common carp & Mono & $12.5 \pm 1 b$ & $4.5 \pm 0.5 b$ & $63.0 \pm 6.2 b$ & $10.1 \pm 0.6 b$ & $8.4 \pm 0.5 b$ & $1.5 \pm 0.4 \mathrm{c}$ \\
\hline & Tilapia & Poly & $9.4 \pm 1 b$ & $4.0 \pm 0.5 b$ & $69.0 \pm 7.5 \mathrm{a}$ & $10.8 \pm 0.6 b$ & $5.5 \pm 0.5 b$ & $1.3 \pm 0.3 c$ \\
\hline & Mullet & Poly & $8.2 \pm 1 b$ & $3.5 \pm 0.4 b$ & $72.3 \pm 6.8 \mathrm{a}$ & $7.7 \pm 0.5 b$ & $6.2 \pm 0.4 \mathrm{c}$ & $2.1 \pm 0.5 b$ \\
\hline & Common carp & Poly & $14.2 \pm 1 b$ & $4.4 \pm 0.5 b$ & $61.2 \pm 5.2 b$ & $10.80 \pm 0.6 b$ & $7.9 \pm 0.6 b$ & $1.5 \pm 0.4 \mathrm{c}$ \\
\hline \multirow{6}{*}{ Artificial } & Tilapia & Mono & $46.5 \pm 4 b$ & $5.2 \pm 0.4 \mathrm{a}$ & $11.4 \pm 1.1 \mathrm{~b}$ & $26.6 \pm 1.5 b$ & $8.2 \pm 0.5 b$ & $2.1 \pm 0.5 b$ \\
\hline & Mullet & Mono & $44.2 \pm 3 a$ & $4.5 \pm 0.4 b$ & $13.1 \pm 1.2 \mathrm{c}$ & $27.5 \pm 1.4 \mathrm{a}$ & $8.2 \pm 0.4 a$ & $2.5 \pm 0.3 \mathrm{a}$ \\
\hline & Common carp & Mono & $47.7 \pm 3 a$ & $5.5 \pm 0.3 b$ & $11.8 \pm 1.1 \mathrm{c}$ & $24.4 \pm 1.6 a$ & $8.5 \pm 0.5 b$ & $2.1 \pm 0.5 b$ \\
\hline & Tilapia & Poly & $46.4 \pm 3 b$ & $5.5 \pm 0.4 \mathrm{a}$ & $10.0 \pm 1 b$ & $27.8 \pm 1.5 b$ & $8.2 \pm 0.5 b$ & $2.1 \pm 0.5 b$ \\
\hline & Mullet & Poly & $44.2 \pm 3 a$ & $4.0 \pm 0.4 b$ & $13.4 \pm 1.1 \mathrm{c}$ & $27.5 \pm 1.4 \mathrm{a}$ & $8.4 \pm 0.4 a$ & $2.5 \pm 0.7 \mathrm{a}$ \\
\hline & Common carp & Poly & $47.7 \pm 3 a$ & $5.2 \pm 0.3 b$ & $11.7 \pm 1.1 \mathrm{c}$ & $24.4 \pm 1.6 \mathrm{a}$ & $8.9 \pm 0.5 b$ & $2.1 \pm 0.6 b$ \\
\hline
\end{tabular}

Means in the column followed by different letters are significantly different $(\mathrm{P}<0.05)$. 


\title{
العوالق الحيوانية كغذاء حى لثلاثة انواع مختلفة من الأسماك فى الاستزراع الأحادى والمتعدد بالأحواض اضع الخرساتية من الأيمة
}

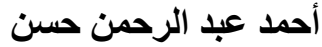 \\ قسم بحوث انتاج الأسماك ونظم الاستزر اع السمكى بالمعمل المركزي لبحوث البرث الثروة السمكي بالعباسن

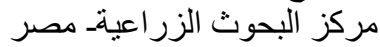 \\ الملخص العربى عالزئ

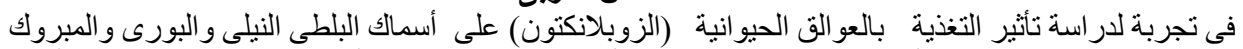

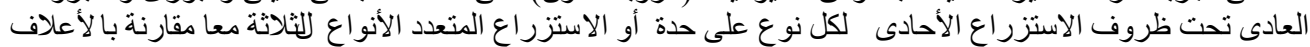

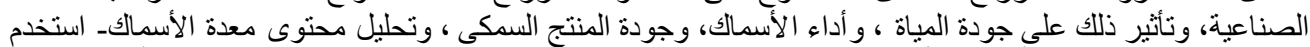

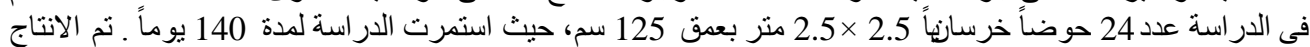

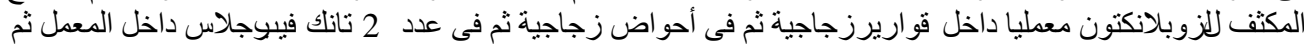

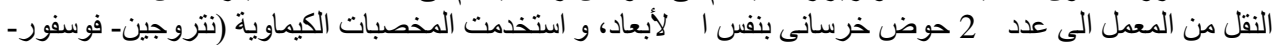

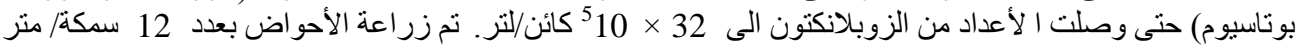

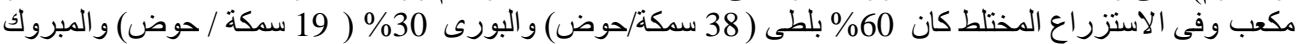

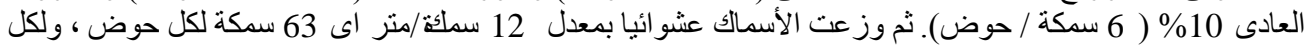

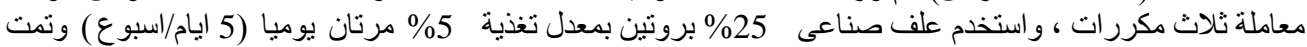

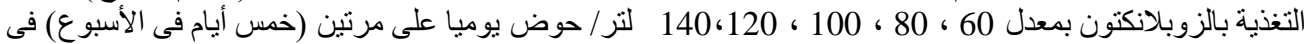

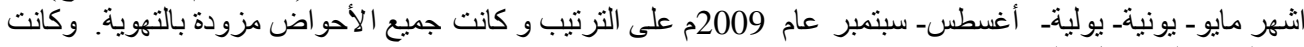

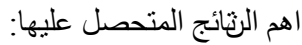

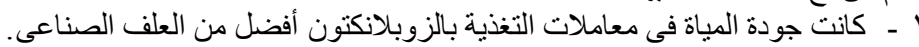

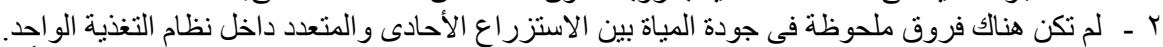

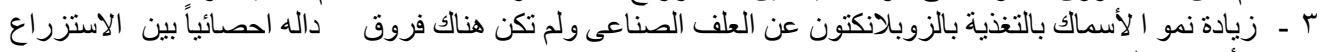
الأحادى و المتعدد.

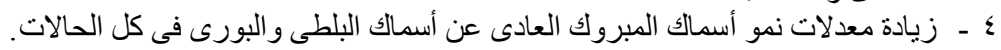

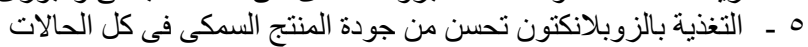

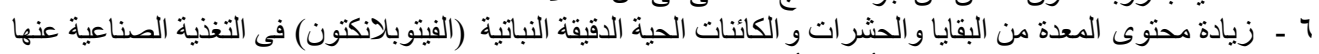

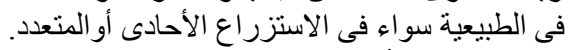

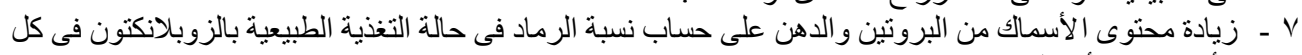

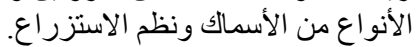

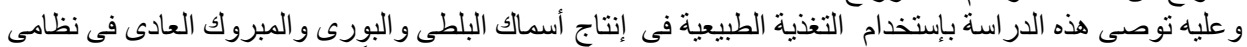

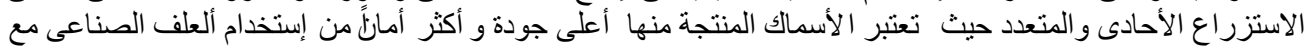

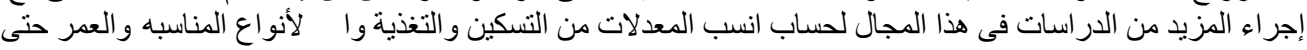

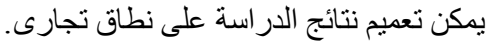

